\title{
RECOMMENDATIONS ON THE TREATMENT OF MERCHANT SEAMEN
}

along lines different from those which have been adopted in Great Britain. Surely the House of Commons ought to have been informed by the Minister of Health of what comparative information was available in regard to the different schemes ! No facts were given in regard to the treatment of the diseases in the Dominions. There has, for example, been a new Venereal Diseases Prevention Act passed in Ontario, which is much wider in scope than anything which has been attempted here (see the explanation on pp. 486-489 of the Canadian Public Health Journal, October, 1942). There must also be a considerable volume of statistical information available in regard to the many states of the United States of America which have adopted special legislation. It might indeed, have been worth while to have made public in the debate the experience gained even in Great Britain during the war of 1914-18. Has it, for example, been established whether Regulation 40D of the Defence of the Realm Regulations passed during that war really assisted in lessening the number of infections? Medical practitioners will probably feel that more purpose would be served by all available information being collected and made readily accessible, than by debates being conducted in the somewhat heated way in which the House of Commons debate was in part conducted, without there being adequate information to support most of the allegations which were made.

From this point of view it does seem unfortunate that the Ministry has not seen fit to require local authorities to furnish regular returns in such a form that the effect of the present regulation could be better observed.

\section{RECOMMENDATIONS OF THE MINISTRY OF HEALTH ON THE TREATMENT OF MERCHANT SEAMEN}

Issued in March, 1943.

The following recommendations apply only to early cases.

\section{A. Gonorrhoea}

(1) When the disease is discovered whilst the seaman is ashore, it is assumed that the diagnosis will be established by laboratory tests ; that the patient will be treated with 4 to 5 grammes sulphathiazole or sulphadiazine daily for four to seven days, this treatment being supplemented by urethral irrigations ; and that if he responds normally to this treatment, he will be tested for cure by well recognized methods.

On this assumption, if no sign of persistence of the infection is discovered seven days after suspension of treatment, the patient should be discharged to full duty.

It is important, however, that in his own interest the patient be re-examined at the end of about three months when he should also be tested for syphilis.

(2) If the disease is discovered whilst the seaman is at sea in a ship not carrying a surgeon, he should be treated with sulphathiazole or with sulphadiazine by a ship's officer as follows :-Six tablets of 0.5 gramme to be taken twice daily for a maximum of five days. Each dose to be crushed up by the teeth and swallowed with a tumblerful of water.

Throughout this treatment and for two days thereafter the patient should drink five pints of water daily.

On arrival at a port provided with a V.D. treatment centre, he should be directed to attend at a treatment centre to be tested for cure, the tests including one for syphilis, and a final test of cure with a test for syphilis should be carried out in a treatment centre not less than three months after completion of the treatment.

(3) If the disease is discovered when the seaman is at sea in a ship carrying a surgeon, the procedure should be like that set out in (1) or in (2) according to the facilities available on the ship for microscopical examination and for treatment as 


\section{THE BRITISH JOURNAL OF VENEREAL DISEASES}

practised in a treatment centre. On arrival in port, tests of cure should be carried out as in (2).

\section{B. Syphilis}

(1) It is strongly recommended that when signs suggestive of syphilis appear no antisyphilitic treatment be given until the diagnosis has been confirmed by laboratory tests. If the seaman is at sea in a ship not carrying a surgeon the only general treatment should be with sulphathiazole or sulphadiazine on the same lines as in A. (2) above and the only local application either salt solution (a teaspoonful in half a tumblerful of water) or sulphanilamide powder. If the seaman is at sea in a ship carrying a surgeon who is convinced on clinical grounds that the patient is suffering from syphilis, the surgeon can start treatment after taking specimens for microscopical and serological examination.

(2) On establishment of the diagnosis at a treatment centre, the director may in certain cases decide to try a modification of the five-day intravenous drip treatment, concerning the details of which no recommendation is required here.

In such cases it would be necessary to admit the patient to hospital. The total period off duty would depend on the exact form of the modification adopted but would not normally exceed three weeks.

On discharge a patient so treated could resume duty but should be tested at intervals of three to six months for at least two years.

The form of treatment just mentioned is not yet suitable for general adoption, and in most cases a modification of the prolonged treatment recommended by the League of Nations Committee of Experts on Syphilis and Cognate Subjects will be necessary. The Conference recommends the following :-

(3) For men ashore who will return to deep-sea service in ships not carrying surgeons, and for men on coast-wise service for whom a weekly injection is impracticable.

(a) .

$$
\begin{aligned}
& \text { neoarsphenamine (I.V.) } \\
& \text { arsphenamine diglucoside (I.V.) } \\
& \text { or sulpharsphenamine (I.M.) }
\end{aligned}
$$

Day
lst

4th

8th

11 th

15 th

18 th

22nd

25 th

29th

32nd

36 th

39th gramme.

0.45

0.45

0.45

0.45

0.45

0.45

0.45

0.45

0.45

0.45

0.45

0.45
Bismuth compound containing the following weights of Bi-metal gramme

0.15

$0 \cdot 15$

0.15

0.15

$0 \cdot 15$

0.15

0.15

0.15

0.15

.0 .15

0.15

$0 \cdot 15$

As it is vitally important that this course should be given with perfect regularity, the patient should remain ashore, in attendance at a centre where two injections can be given weekly. In-patient treatment should not normally be necessary. The question of the patient's ability to work or otherwise whilst undergoing this treatment should be left to the discretion of the medical officer.

(b) Interval, three to six months.

(c) If blood serum negative, treatment as in (a) from 1st to 29th days. If positive, treatment as in (a) for 39 days. If a medical officer feels that, notwithstanding the blood serum's being negative, it would be in the best interests of all concerned that a seaman should have the full 39 . days course, the full course may be given.

(d) Repeat (b) and (c) once.

(e) Blood test every three to six months for a minimum of two years. 
(4) For men on deep-sea service in ships carrying surgeons.

(a) As in 3(a), remaining ashore.

(b) Interval, three to six months.

(c) If the ship's surgeon can undertake full treatment, after three months repeat as in 3(c), on the ship. If the ship's surgeon cannot undertake the treatment, continue as for men in ships not carrying surgeons.

(d) Repeat (b) and (c) once.

(e) Blood tests every three to six months for a minimum of two years.

(5) For men on coast-wise service provided that one attendance can be made each week.

(a) Ten weekly injections of 0.60 gramme neoarsphenamine, arsphenamine diglucoside, or sulpharsphenamine, concurrently with the same number of a bismuth compound containing $\theta .2$ to 0.3 gramme bismuth metal.

(b) Interval, one month.

(c) Repeat (a) and (b) twice.

(d) Blood test every three to six months for a minimum of two years.

(See Editorial on Treatment of Venereal Diseases in Seamen, in this issue.)

\section{ANNOTATIONS \\ AN ELEGANT EARLY 18th CENTURY PIECE OF V.D. PROPAGANDA}

\section{AN ESSAY ON NOSES BY JOSEPH ADDISON, " TATLER," THURSDAY, DECEMBER 7th, 1710}

Interest in enlightenment of the public on venereal diseases has recently been revived after lying dormant for nearly a quarter of a century, and the amusing essay reprinted below may remind readers that the subject is not new. An excuse does not seem to be necessary for its reproduction here as few specialists in venereal diseáses seem to know of its existence. In a paper by Dr. J. D. Rolleston read before the Medical Society for the Study of Venereal Diseases and published in this Journal, 1934, 10, 147, the essay was attributed to Steele, but it appeared in the collection by Tickell, Addison's literary executor, in the preface to which is is stated: "It was necessary that his share in the Tatlers should be adjusted in a complete collection of his works ; for which reason Sir Richard Steele, in compliance with a request of his deceased friend, delivered to him by the editor, was pleased to mark with his own hand those Tatlers which are inserted in this edition, and even to point out several in the writing of which they both were concerned.",

\section{Non cuicumque datum est habere nasum.-Mart.}

L. W. H.

From my own Apartment, December 6.

We have a very learned and elaborate dissertation upon thumbs in Montaigne's Essays, and another upon ears in the Tale of a Tub. I am here going to write one upon noses, having chosen for my text the following verses out of Hudibras:

So learned Talicotius from

The brawny part of porter's bum

Cut supplemental noses which

Lasted as long as parent breech ;

But when the date of nock was out,

Off dropped the sympathetic snout.

Notwithstanding that there is nothing obscene in natural knowledge, and that $I$ intend to give as little offence as may be to readers of a well-bred imagination, I must, for my own quiet, desire the critics (who in all times have been famous for good noses) to refrain from 